\title{
PHENOLOGICAL CYCLE AND DIURNAL VARIATION EFFECTS ON THE VOLATILE OIL CHARACTERISTICS OF SAGE (Salvia officinalis L.)
}

\author{
Amir SOLTANBEIGI $^{1 *}$, Elnaz SAMADPOURRIGANI ${ }^{2}$ \\ ${ }^{1}$ Department of Basic Pharmaceutical Sciences, Faculty of Pharmacy, Afyonkarahisar Health Sciences University, \\ Afyonkarahisar, TURKEY \\ ${ }^{2}$ Ambaryolu St. Apt. 15, Afyonkarahisar, TURKEY. \\ Cite this article as: \\ Soltanbeigi A. \& Samadpourrigani E. 2021. Phenological cycle and diurnal variation effects on the volatile oil characteristics of sage (Salvia officinalis \\ L.). Trakya Univ J Nat Sci, 22(1): 59-65, DOI: 10.23902/trkjnat.815752
}

Received: 24 October 2020, Accepted: 26 March 2021, Online First: 07 April 2021, Published: 15 April 2021

Edited by:

Mehmet Bora Kaydan

*Corresponding Author:

Amir Soltanbeigi

amir.soltanbeigi@afsu.edu.tr

ORCID iDs of the authors:

AS. orcid.org/0000-0002-7891-0491

ES. orcid.org/0000-0003-3768-8147

Key words:

Diurnal

Essential oil

GC-MS

Ontogeny

Salvia officinalis

\begin{abstract}
This study was carried out to evaluate the effects of phenological and diurnal variation on volatile oil content and quality of Salvia officinalis L. (Lamiaceae) cultivated in Afyonkarahisar/Turkey. The harvesting times based on ontogeny were the pre-flowering, flowering and post-flowering stages. The harvesting took place three times a day, at 6:00 a.m., 2:00 and 8:00 p.m. The results showed that the highest volatile oil was obtained at 8:00 p.m. of the flowering stage $(2.05 \%)$. In general, the best harvesting time was the flowering stage and the last hours of the day. The synthesis of volatile oil was almost the same at other phenological stages. The amount of volatile oil increased at the sunset time of the day in all studied stages. Among the identified of S. officinalis volatile oil compounds, oxygenated monoterpenes were the largest chemical group (52.8-68.6\%). $\alpha$-Thujone (13.0-35.8\%) was the major compound of the most samples. The highest and lowest values of this compound were observed in the post-flowering and flowering stages, respectively. The other main compounds were camphor (7.0-20.2\%), 1,8-cineole $(6.9-14.1 \%)$, borneol $(2.8-15.8 \%)$ and veridiflorol (4.5-12.3\%). The effects of climatic factors such as day length, insolation, temperature and plant growth stage affected the quantity and quality of volatile oil content of S. officinalis. The results showed that the best harvesting time for S. officinalis for volatile oil content is 8:00 p.m. at the flowering stage in Afyonkarahisar climatic conditions. The volatile oil compositions of the plant varied widely at different harvest times (ontogeny and diurnal).
\end{abstract}

Özet: Bu çalışmada Afyonkarahisar'da yetiştirilen Salvia officinalis L. (Lamiaceae) uçucu yağ oranı ve kalitesi üzerindeki fenolojik evre ve diurnal varyabilite etkileri araştırılmıştır. Ontogenetik varyabiliteye dayalı hasat zamanları çiçeklenme öncesi, çiçeklenme dönemi ve çiçeklenme sonrası olarak belirlenmiştir. Diurnal varyabilite olarak hasat saatleri 06:00, 14:00 ve 20:00 ayarlanmıştır. Sonuçlara göre en yüksek uçucu yağ çiçeklenme döneminde ve saat 20:00'de $(\% 2,05)$ elde edilmiştir. En iyi hasat zamanı çiçeklenme dönemi ve günün son saatleri olarak saptanmıştır. Diğer fenolojik evrelerde uçucu yağ sentezi neredeyse aynı oranda bulunmuştur. Ayrıca, çalışılan tüm evrelerde uçucu yağ içeriği günün son saatlerine doğru artmıştır. Salvia officinalis uçucu yağının tanımlanan bileşikleri arasında oksijenli monoterpenler en büyük kimyasal gruba sahip olmuştur (\%52,8-68,6). $\alpha$-Thujone $(\% 13,0$ $35,8)$ deneme örneklerinin çoğunda ana bileşik olarak belirlenmiştir. Bu bileşiğin en yüksek ve en düşük değerleri sırasıyla çiçeklenme sonrası ve çiçeklenme aşamalarında gözlenmiştir. Camphor $(\% 7,0-20,2), 1,8$-sineol $(\% 6,9-14,1)$, borneol $(\% 2,8-15,8)$ ve veridiflorol $(\% 4,5-$ 12,3) diğer önemli bileşikler olarak tanımlanmıştır. Salvia officinalis uçucu yağının miktarı ve kalitesi üzerinde gün uzunluğu, güneşlenme, sıcaklık gibi iklim faktörleri ve bitki büyüme evresi etkileri belirgin bir şekilde ortaya çıkmıştır. Bu çalışmanın sonuçları doğrultusunda, $S$. officinalis'in en uygun hasat zamanı Afyonkarahisar koşullarında çiçeklenme dönemi ve saat 20:00 olarak belirlemiştir. Bitkinin uçucu yağ bileşenleri, farklı hasat zamanlarında (ontogenetik ve diurnal) geniş değişim göstermiştir.

\section{Introduction}

Salvia officinalis L. (common sage), as a woody perennial herb, is one of the most important commercial species of the genus Salvia which includes nearly 1000 species throughout the Old and New Worlds (Lakušić et al. 2013). Salvia officinalis is native to the Mediterranean region but does not exist naturally in Turkey (Sönmez \& 
Bayram 2017). The cultivation of $S$. officinalis has recently become common in different regions of Turkey. This plant has anti-oxidant, anti-diabetic, antiinflammatory, anti-bacterial, anti-viral, anti-fungal, antianxiety, memory-improving and hypoglycemic activities and there exist reports on its protective effects against Alzheimer, cardiovascular diseases and cancer (Grdiša et al. 2015, Miraj \& Kiani 2016). It is also used as a diuretic, a local anesthetic for the skin, a styptic, traditionally (Bozin et al. 2007). The extensive therapeutic properties of $S$. officinalis are mainly related to bioactive compounds, especially its volatile oils (VOs) (Rguez et al. 2018). Camphor (23.6-32.5\%), $\alpha$-thujone (11.3-28.5\%), 1,8-cineole (7.9-9.5\%), camphene (6.2-8.6\%), $\beta$-thujone (4.6-10.5\%), $\alpha$-pinene (3.2-5.9\%), borneol (3.1-4.2\%), $\beta$ pinene $(2.3-2.7 \%)$, viridiflorol $(2.5-3.9 \%), \alpha$-humulene (1.9-3.1\%) and manool (1.0-2.9\%) were determined as the major chemical components of S. officinalis (Katar et al. 2019).

The production of secondary metabolites in plants as bioactive chemicals is a natural response to biotic and abiotic stresses that improve plant resistance to adverse conditions (Ramakrishna \& Ravishankar 2011). The biosynthesis of secondary metabolites in terms of quality and quantity, although controlled genetically, is strongly affected by the climatic conditions, environment organisms, applied agro-techniques, harvesting time and post-harvesting processing (Miguel et al. 2004, Soltanbeigi \& Sakartepe 2020). In other words, the volatile oil synthesis depends on the interaction between genetic, ontogenesis and physiological state of the plant with environmental conditions. The regulation of the volatile compounds is further complicated by dynamic differential components of abiotic factors such as edaphic properties, moisture, temperature and light intensity (Lee \& Ding 2016). Ontogeny acts as a timeline for plant growth, which has a major role in determining the maximum accumulation time of volatile oils (Verma et al. 2012). The accumulation pattern of secondary metabolites in plants is characterized by diurnal fluctuation due to enzymatic activities, temperature and light (Asghari et al. 2014). Knowledge of factors that increase the quality and quantity in agro-ecosystems is necessary. These factors largely depend on the type of plant that can be considered to achieve cultivation aim. Therefore, methods that can produce a healthy medicinal plant with more effective substances may be needed (Azarnivand et al. 2010). Since climatic conditions cannot be controlled and managed, planting time, agronomic practices and especially harvesting time are the most critical factors in the optimal production of volatile oil and its quality (Lakušić et al. 2013, Katar et al. 2019).

This study aimed to determine the appropriate harvest time for S. officinalis in terms of ontogenetic and diurnal variability in Afyonkarahisar climate conditions.

\section{Materials and Methods}

\section{Plant Material, Location}

The plant material was 3-year-old Salvia officinalis. The samples were obtained from an ongoing study in Afyonkarahisar Medicinal and Aromatic Plants Centre $\left(38^{\circ} 46^{\prime} \mathrm{N}, 30^{\circ} 30^{\prime} \mathrm{E}\right)$ located in Turkey's inner Aegean region. The region is characterized as a transitional climate zone affected by three main climatic conditions seen in the Mediterranean (South), Central Anatolia (East) and Aegean (West) regions. The climate of the experimental location is harsh, with moderate rainy. Most precipitation occurs in winter and spring. Summers are hot and dry and winters are cold and snowy. Some meteorological data during the sampling season are given in Table 1 and some physico-chemical properties of the soil of the sampling area are given in Table 2 .

\section{Treatments}

Plants allocated for sampling were grown following sustainable farming methods. Samples were taken at three different growth and developmental stages (ontogenetic variability) and three different hours of the day (diurnal variability). The pre-flowering (1 June), full flowering (24 July) and post-flowering (29 August) stages were chosen for ontogenetic variability samples. The hours for diurnal diversity were 6:00 a.m., 2:00 p.m. and 8:00 p.m. The plant samples were cut from $5-8 \mathrm{~cm}$ and were separated to leaves and stems. The leaves were dried at $37^{\circ} \mathrm{C}$ in a cabinet type dryer for 72 hours.

Table 1. Some local meteorological data of the experimental field in 2019.

\begin{tabular}{ccccccc}
\hline \hline Months & $\begin{array}{c}\text { Min. } \\
\text { Temperature } \\
\left({ }^{\circ} \mathbf{C}\right)\end{array}$ & $\begin{array}{c}\text { Temperature } \\
\left({ }^{\circ} \mathbf{C}\right)\end{array}$ & $\begin{array}{c}\text { Mean } \\
\text { Temperature } \\
\left({ }^{\circ} \mathbf{C}\right)\end{array}$ & $\begin{array}{c}\text { Precipitation } \\
(\mathbf{m m})\end{array}$ & $\begin{array}{c}\text { Relative } \\
\text { humidity } \\
(\boldsymbol{\%})\end{array}$ & $\begin{array}{c}\text { Exposure to sun } \\
\text { rays } \\
(\mathbf{h})\end{array}$ \\
\hline \hline January & -1.5 & 5.2 & 1.6 & 58.7 & 78.7 & 72.3 \\
February & 0.3 & 8.5 & 4 & 35.3 & 71.3 & 104.5 \\
March & 1.4 & 12.8 & 6.8 & 10.9 & 58 & 185.2 \\
April & 4.3 & 15.2 & 9.5 & 21.3 & 61.5 & 150.8 \\
May & 10.4 & 23.2 & 16.7 & 44.1 & 53.5 & 249.1 \\
June & 14.5 & 26.7 & 20.5 & 78.4 & 58.3 & 232.3 \\
July & 14.9 & 28.5 & 21.9 & 29.1 & 49.1 & 325.3 \\
August & 16.2 & 29.5 & 22.8 & 4.5 & 47.4 & 286.7 \\
September & 12 & 26.8 & 19.4 & 2.7 & 48.1 & 270.1 \\
\hline \hline
\end{tabular}

Turkish State Meteorological Service 
Table 2. The values of some physico-chemical properties of the experimental soil.

\begin{tabular}{lclc}
\hline \hline \multicolumn{1}{c}{ Properties } & $(\boldsymbol{\%})$ & Elements & (ppm) \\
\hline \hline Organic matter content & 1.84 & $\mathrm{Ca}$ & 3287 \\
Total N & 0.14 & $\mathrm{Mg}$ & 577 \\
Sand & 46.41 & $\mathrm{~K}$ & 783 \\
Clay & 32.98 & $\mathrm{Na}$ & 80 \\
Dust & 20.61 & $\mathrm{Fe}$ & 0.21 \\
Lime & 3.14 & $\mathrm{P}$ & 109 \\
Field capacity & 27.43 & $\mathrm{Cu}$ & 2.3 \\
Wilting point & 17.01 & $\mathrm{Zn}$ & 0.17 \\
Available moisture & 10.41 & $\mathrm{Mn}$ & 1.91 \\
\hline \hline
\end{tabular}

Soil class: Sandy clay; EC $\left(\mathrm{mS} \mathrm{cm}^{-1}\right): 0.19 ; \mathrm{pH}: 8.37$

\section{Volatile oil isolation}

For VO isolation, 50 grams of dry leaves were subjected to hydro-distillation with distilled water (1:10) by a neo-Clevenger type apparatus for three hours in 3 replications. The VO content was determined volumetrically $\left(\mathrm{mL} 100 \mathrm{gr}^{-1}\right)$. After decantation, the VO samples were dried over anhydrous sodium sulfate and kept in amber vials at $-4^{\circ} \mathrm{C}$.

\section{Identification of chemical compounds}

The chromatographic analysis was conducted by a gas chromatography (GC) system (Agilent 7890B-USA) equipped with a flame ionization detector (FID) and coupled to a mass spectrometry detector (MSD) (Agilent 5977A-USA) under electron impact ionization $(70 \mathrm{eV})$. The MS scan range was 50-550 atomic mass units (AMU). The column for the separation of the compounds was HP-Innowax (Agilent 19091N-116: $60 \mathrm{~m} \times 0.320$ $\mathrm{mm}$ internal diameter and $0.25 \mu \mathrm{m}$ film thickness). The carrier gas was helium at a flow rate of $1.3 \mathrm{~mL} \mathrm{~min}^{-1}$. The detector, injector and ion source temperatures were $270^{\circ} \mathrm{C}, 250^{\circ} \mathrm{C}$ and $230^{\circ} \mathrm{C}$, respectively. Injection volume was set at $1 \mu \mathrm{L}(20 \mu \mathrm{L}$ VO was diluted in $1 \mathrm{~mL}$-Hexane) in split mode (40:1). The samples were analyzed with the column held initially at $70^{\circ} \mathrm{C}$ for 5 min hold time. Then, the temperature was raised to $160^{\circ} \mathrm{C}$ with a $3^{\circ} \mathrm{C} \mathrm{min}-1$ heating ramp and $5 \mathrm{~min}$ hold time. Eventually, the temperature reached to $250^{\circ} \mathrm{C}$ with a $6^{\circ} \mathrm{C} \mathrm{min}^{-1}$ heating ramp and 5 min hold time. For accurate determination of chemical compounds, the retention indices (RI) were calculated by injecting $\mathrm{C}_{7}-\mathrm{C}_{30} \mathrm{n}$-alkanes (Sigma-AldrichUSA) to (GC/FID) system (Agilent 7890B-USA) under the same conditions of the VO analyses. The identifications of the VO components were performed by comparing retention indices, mass spectra by the computer library database of US National Institute of Standards and Technology (NIST), Wiley libraries, other published mass spectra data (Adams 2007) and our database. Relative abundance (\% area) was calculated based on the ratio between each compound's peak area and the sum of areas of all compounds. No response factors were calculated.

\section{Results and Discussions}

The distillation step revealed that the samples' VO content varied by different growth stages and different hours of the day $\left(1.0-2.05 \mathrm{~mL} 100 \mathrm{gr}^{-1}\right)$. In terms of ontogenetic variability, the maximum VO contents was obtained from samples taken in the full flowering stage (1.4-2.05 mL 100 $\left.\mathrm{gr}^{-1}\right)$. The VO content VO increased diurnally in all three stages of the harvests as hours

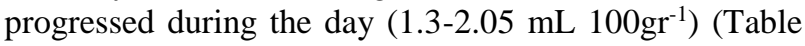
$3)$. Although genetics is considered to be the crucial determinant of quantity and quality (Lee \& Ding 2016), it is inferred that in addition to agricultural practices, plant age, day length, light intensity, day and night temperature changes and relative humidity affect the VO content (Soltanbeigi 2020). Based on European Pharmacopoeia (2005) standards, the minimum VO content of S. officinalis should not be less than $1.5 \%$ in dried leaves. According to Paulus et al. (2019), the sunlight (quality, intensity and duration) has the most effect on VO synthesis. The flowering stage in this study coincided with July, when the plants received most of the light intensity (Table 1). BenFarhat et al. (2016) showed that the best time to harvest $S$. officinalis is the flowering stage $(1.49 \%)$ in terms of VO content. Besides, the process of biosynthesis of VOs in plants takes place only in very young cells. Since the accumulation of VO is directly related to leaf ontogeny, its synthesis rate is rapid in the early stages of leaf growth. With increasing leaf weight, its VO content remains almost constant (Nurzyńska-Wierdak et al. 2012). Ramezani et al. (2009) indicated the temperature variation during the day has more effect on VO accumulation. More recently, Rguez et al. (2018) reported an increase in S. officinalis VO content from morning to afternoon (7 a.m.: $0.78 \%, 12$ noon: $0.93 \%$ and 5 p.m.: $1.1 \%$ ).

A total of 44 components were obtained as a result of GC-MS analyses (Table 3). The highest number of components was found at 2:00 p.m. sample related to the pre-flowering stage. The least component was obtained at 2:00 p.m. in the full flowering stage. Some components were not found in different growth stages and different times of the day. For instance, tricyclene, sabinene and 1octen-3-ol were not found in the pre-flowering samples, sabinyl acetate, alloaromadendrene and (+)-spathulenol were not detected in the pre-flowering and flowering stages, cis-Ocimene, $\alpha$-copaene, linalool and propanal, 2 methyl-3-phenyl- did not appear in the flowering and post-flowering stages. Aromadendrene and $\gamma$-cadinene were not identified in the flowering and post-flowering stages, respectively.

Oxygenated monoterpenes were the main chemical group at different phenological stages with a considerable difference (52.8-68.6\%) (Table 3). The highest accumulation of oxygenated monoterpenes occurred in the post-flowering stage, followed by flowering and preflowering stages, respectively. In other words, with the aging of the plants, the amounts of oxygenated monoterpenes increased. Although the highest level of oxygenated monoterpenes was observed at 8:00 p.m. of 
the pre-flowering stage, this group's amounts were higher in the morning harvests (6:00 a.m.) of flowering and postflowering stages. This group was followed by hydrocarbon sesquiterpenes (6.6-19.6\%), hydrocarbon monoterpenes (4.7-14.3\%), oxygenated sesquiterpenes (7.0-13.6\%), oxygenated diterpenes (2.1-6.5\%) and esters $(0.6-4.5 \%)$. The highest level of hydrocarbon monoterpenes was observed in the flowering and postflowering stages. This group lacked specific behavior in terms of diurnal changes. However, the total amount of monoterpenes (oxygenated monoterpenes + hydrocarbon sesquiterpenes) in VO was highest at 6:00 a.m. Levels of both oxygenated sesquiterpenes and sesquiterpene hydrocarbons decreased with the aging of the plants. This state was in contrast to monoterpene's behavior. Epimanool, as a labdane diterpenoid, was the only oxygenated diterpene in VO samples of $S$. officinalis. The highest amounts of this composition were identified in the pre-flowering stage. As the hour progresses during the day, the values of this compound increased in all three phenological stages. Also, the highest accumulation of esters was in the flowering stage (Table 3). According to Piccaglia et al. (1997) low light and low temperatures at harvest time are likely to cause internal conversions between monoterpenes and sesquiterpenes. Increased oxygenated monoterpenes of $S$. officinalis VO in the postflowering stage (fruiting) have been reported by Ben-Farhat et al. (2016) and Mirjalili et al. (2006). In the study of Lakušić et al. (2013) on S. officinalis, the total monoterpene compounds increased in the warm months of the year and at the same time, the sesquiterpene compounds decreased, as in the case of our findings. The amount of monoterpene hydrocarbons at the flowering stage was also reported to be higher than at other phenological stages (Mirjalili et al. 2006), similar to our findings, but the sum of monoterpenes was higher in the flowering stage. Rguez et al. (2018) indicated that the amount of oxygenated monoterpenes in the late afternoon hours of the day (5:00 p.m.) was at the highest level and monoterpene hydrocarbons were at the lowest level. But the sum of these two groups increased as the hour progresses during the day.

Except for the samples taken at 2:00 p.m. and 8:00 p.m. in the flowering stage, $\alpha$-thujone (13.0-35.8\%) was identified as the major compound of $S$. officinalis VO. The lowest $(13.0 \%)$ and highest $(35.8 \%)$ content of $\alpha$ thujone was found at 8:00 p.m. in the flowering stage and 2:00 p.m. in the post-flowering samples, respectively. In terms of ontogenetic variation, the highest $\alpha$-thujone content was in the after-flowering stage (32.3-38.8\%). The pre-flowering and flowering stages followed the postflowering stage. The highest $\alpha$-thujone in the preflowering and flowering stages were recorded at 6:00 a.m. (23.8 and 19.2\%) (Table 3 ). According to the observations of Mirjalili et al. (2006) and Ben-Farhat et al. (2016), the maximum amount of $\alpha$-thujone was in the post-flowering stage (fruiting stage) and the lowest level was in the flowering stage. Katar et al. (2019) also reported the highest amounts of this compound in the full-flowering and fruiting-set stages. As the aging of S. officinalis, $\alpha-$ thujone biosynthesis accelerates, which almost coincides with the warmer months of the year (Lakušić et al. 2013). A study that examined diurnal variations in S. officinalis VO compositions, $\alpha$-thujone showed no clear response to hour changes (Rguez et al. 2018).

The other main constituents identified were camphor (7.0-20.2\%), 1,8-cineole (6.9-14.1\%), borneol (2.8$15.8 \%)$ and veridiflorol (4.5-12.3\%). The highest camphor content was found at 2:00 p.m. sample in the flowering stage $(20.2 \%)$, and the lowest content was seen at 6:00 a.m. of pre-flowering. Although this compound's highest and lowest values were observed at 2:00 p.m. and 6:00 a.m. samples in the flowering and pre-flowering stages, this was not the case in the post-flowering stage. According to $\alpha$-thujone and camphor action, it was observed that with the raising of $\alpha$-thujone content, the content of camphor decreased in each growth stage. The highest content of 1,8-cineole $(14.1 \%)$ was found in the pre-flowering stage. The highest values of this component were detected at 6:00 a.m. samples in all three growth stages. Besides, as the plants got older, 1,8-cineole biosynthesis was adversely affected. The greatest formation of borneol occurred during the flowering stages $(10.2-15.8 \%)$. An increase was observed in the content of this compound from early morning hours to sunset. The highest and lowest contents of veridiflorol were identified at 2:00 p.m. sample of pre-flowering and the 6:00 a.m. sample of post-flowering, respectively. Veridiflorol contents decreased with plant aging. The other important compounds of $S$. officinalis VO were $\alpha$-pinene (0.6$4.2 \%)$, camphene (1.0-5.2\%), $\beta$-pinene $(0.7-2.6 \%), \beta$ thujone $(1.1-4.9 \%)$, caryophyllene $(2.1-8.6 \%), \quad \alpha$ humulene $(3.3-10.9 \%)$, and epimanool $(2.1-6.5 \%)$. $\alpha$ Pinene and camphene had higher contents in the postflowering and flowering stages, respectively. $\beta$-thujone was found in minimal quantities during the flowering stage. The highest contents for caryophyllene, $\alpha$ humulene and epimanool were seen in the post-flowering stage. However, these components do not have clear action in terms of diurnal variability.

According to the current findings, the chemical components of plant VO were not stable during the growing season and at different times of the day. In addition to the genetic makeup of the plants (Sedlakova et al. 2003), the climatic conditions, agronomic management, harvesting time and post-harvest processing affect the synthesis of secondary metabolites (Özgüven et al. 2008). The variation in the amounts of constituents could be due to seasonal changes and climate changes during the day (Bouaziz et al. 2009). In addition, day length (presence of light) and solar intensity cause the plant's photochemical reaction and change in the accumulation of secondary metabolites and their constituents (Ben-Taarit et al. 2010). According to Bradley (2006), the main compounds of the $S$. officinalis are $\alpha$-thujone (10-60\%), $\beta$-thujone (4$36 \%)$, camphor $(5-20 \%), 1,8$-cineole $(1-15 \%)$. Cisthujone $(18-43 \%)$, trans-thujone (3-8.5\%), camphor 
Table 3. The content and chemical characteristics of Salvia officinalis volatile oil affected by phenological cycle and diurnal variation.

\begin{tabular}{|c|c|c|c|c|c|c|c|c|c|c|}
\hline \multirow[b]{2}{*}{$\mathbf{R I}^{*}$} & \multirow[b]{2}{*}{ Compounds (\%) } & \multicolumn{3}{|c|}{ Pre-flowering Stage } & \multicolumn{3}{|c|}{ Flowering Stage } & \multicolumn{3}{|c|}{ Post-flowering Stage } \\
\hline & & $\begin{array}{l}\text { 6:00 } \\
\text { a.m. }\end{array}$ & $\begin{array}{l}\text { 2:00 } \\
\text { p.m. }\end{array}$ & $\begin{array}{l}\text { 8:00 } \\
\text { p.m. }\end{array}$ & $\begin{array}{l}\text { 6:00 } \\
\text { a.m. }\end{array}$ & $\begin{array}{l}\text { 2:00 } \\
\text { p.m. }\end{array}$ & $\begin{array}{l}\text { 8:00 } \\
\text { p.m. }\end{array}$ & $\begin{array}{l}\text { 6:00 } \\
\text { a.m. }\end{array}$ & $\begin{array}{l}\text { 2:00 } \\
\text { p.m. }\end{array}$ & $\begin{array}{l}\text { 8:00 } \\
\text { p.m. }\end{array}$ \\
\hline 940 & cis-Salvene & 0.31 & 0.16 & 0.08 & 0.35 & 0.12 & 0.18 & 0.4 & 0.11 & 0.37 \\
\hline 1015 & Tricyclene & & & & 0.11 & 0.15 & 0.18 & 0.14 & 1.54 & 0.12 \\
\hline 1028 & $\alpha$-Pinene & 2.72 & 1.27 & 0.67 & 2.31 & 2.25 & 2.76 & 4.2 & 3.53 & 3.7 \\
\hline 1074 & Camphene & 1.03 & 1.64 & 1.25 & 4.67 & 4.4 & 5.29 & 4.03 & 2.02 & 3.61 \\
\hline 1117 & $\beta$-Pinene & 1.58 & 2.04 & 0.79 & 2.39 & 1.91 & 2.67 & 1.41 & 0.91 & 1.42 \\
\hline 1129 & Sabinene & & & & 0.16 & 0.14 & 0.14 & 0.13 & & 0.15 \\
\hline 1168 & $\beta$-Myrcene & 0.55 & 0.51 & 0.23 & 0.71 & 0.58 & 0.58 & 0.71 & 0.57 & 0.7 \\
\hline 1188 & $\alpha$-Terpinene & 0.19 & 0.12 & 0.05 & 0.15 & & 0.12 & 0.16 & 0.17 & 0.16 \\
\hline 1207 & Limonene & 0.77 & 0.89 & 0.59 & 1.48 & 1.65 & 1.74 & 1.49 & 1.07 & 1.39 \\
\hline 1218 & 1,8-Cineole & 14.15 & 13.86 & 13.39 & 13.72 & 7.07 & 7.32 & 8.3 & 6.99 & 8.3 \\
\hline 1240 & cis-Ocimene & 0.97 & 0.71 & 0.51 & & & & & & \\
\hline 1254 & $\gamma$-Terpinene & 0.44 & 0.3 & 0.13 & 0.34 & 0.22 & 0.22 & 0.33 & 0.4 & 0.34 \\
\hline 1257 & trans- $\beta$-Ocimene & 0.22 & 0.15 & 0.13 & & & & & & \\
\hline 1281 & o-Cymene & 0.17 & 0.1 & 0.11 & 0.19 & 0.13 & 0.14 & 0.54 & 0.55 & 0.54 \\
\hline 1292 & $\alpha$-Terpinolene & 0.23 & 0.24 & 0.2 & 0.29 & 0.38 & 0.36 & 0.2 & 0.16 & 0.18 \\
\hline 1442 & $\alpha$-Thujone & 23.83 & 15.78 & 16.22 & 19.22 & 14.98 & 13.04 & 32.73 & 35.8 & 32.32 \\
\hline 1449 & 1-Octen-3-ol & & & & 0.21 & 0.19 & 0.18 & 0.05 & 0.21 & 0.21 \\
\hline 1460 & $\beta$-Thujone & 4.75 & 3.15 & 4.91 & 2.74 & 1.44 & 1.15 & 3.03 & 3.8 & 3.03 \\
\hline 1471 & cis-Sabinene hydrate & 0.15 & 0.22 & 0.18 & 0.25 & 0.26 & 0.2 & 0.15 & & 0.19 \\
\hline 1510 & $\alpha$-Copaene & 0.07 & 0.12 & 0.11 & & & & & & \\
\hline 1543 & Camphor & 7.01 & 10.05 & 9.35 & 15.05 & 20.26 & 19.27 & 19.22 & 12.1 & 14.43 \\
\hline 1547 & Linalool & 0.39 & 0.45 & 0.44 & & & & & & \\
\hline 1556 & trans-Sabinene hydrate & 0.11 & 0.12 & 0.12 & 0.19 & 0.22 & 0.18 & 0.16 & & 0.19 \\
\hline 1598 & (-)-Bornyl acetate & 0.65 & 1.03 & 2.65 & 2.58 & 4.53 & 3.66 & 1.03 & 0.89 & 0.94 \\
\hline 1615 & 4-Terpineol & 0.17 & 0.22 & 0.17 & 0.38 & 0.33 & 0.39 & 0.44 & 0.64 & 0.43 \\
\hline 1623 & Caryophyllene & 8.14 & 8.63 & 6.61 & 4.94 & 3.37 & 3.57 & 2.1 & 2.91 & 2.42 \\
\hline 1633 & Aromadendrene & & 0.15 & 0.12 & & & & 0.3 & 0.35 & \\
\hline 1664 & Sabinyl acetate & & & & & & & 0.14 & 0.29 & 0.11 \\
\hline 1672 & Alloaromadendrene & & & & & & & & 0.12 & 0.25 \\
\hline 1683 & $\alpha$-Terpineol & 0.23 & 0.37 & 0.31 & 0.29 & 0.28 & 0.26 & 0.22 & 0.21 & 0.21 \\
\hline 1697 & $\alpha$-Humulene & 10.91 & 7.65 & 7.55 & 3.8 & 4.2 & 4.52 & 3.3 & 4.16 & 3.4 \\
\hline 1709 & $\alpha$-Amorphene & 0.41 & 1.04 & 0.56 & 1.05 & 1.17 & 1.18 & 0.94 & 0.88 & 0.87 \\
\hline 1716 & Borneol & 2.8 & 8.3 & 11.66 & 10.27 & 15.16 & 15.88 & 3.99 & 3.81 & 5.71 \\
\hline 1777 & $\gamma$-Cadinene & 0.2 & 0.3 & 0.18 & 0.15 & 0.09 & 0.11 & & & \\
\hline 1805 & Myrtenol & 0.21 & 0.1 & 0.14 & 0.16 & 0.23 & 0.24 & 0.38 & 0.36 & 0.31 \\
\hline 1809 & Propanal, 2-methyl-3-phenyl- & 0.18 & 0.25 & 0.1 & & & & & & \\
\hline 2024 & Caryophyllene oxide & 0.47 & 0.48 & 0.31 & 0.8 & 0.78 & 0.7 & 0.86 & 1.2 & 1.19 \\
\hline 2055 & Humulene oxide & 0.19 & 0.09 & 0.14 & 0.09 & 0.11 & 0.1 & 0.16 & 0.23 & 0.18 \\
\hline 2080 & Humulene oxide II & 0.91 & 0.6 & 0.64 & 0.65 & 0.79 & 0.77 & 1.13 & 1.82 & 1.33 \\
\hline 2112 & Veridiflorol & 8.56 & 12.31 & 11.83 & 7.62 & 7.9 & 7.85 & 4.52 & 5.47 & 5.8 \\
\hline 2146 & (+)-Spathulenol & & & & & & & 0.19 & 0.28 & 0.21 \\
\hline 2216 & m-Eugenol & 0.21 & 0.12 & 0.24 & & & 0.16 & & 0.31 & 0.2 \\
\hline 2319 & $\alpha$-Caryophylladienol & 0.22 & 0.17 & 0.19 & 0.21 & 0.24 & 0.18 & 0.2 & 0.33 & 0.28 \\
\hline 2679 & Epimanool & 4.94 & 5.58 & 6.51 & 2.16 & 4.16 & 4.41 & 2.43 & 4.04 & 4.18 \\
\hline Volati & oil content $\left(\mathrm{mL} \mathrm{100gr^{-1 } )}\right.$ & 1 & 1.1 & 1.3 & 1.4 & 1.8 & 2.05 & 0.85 & 1.05 & 1.3 \\
\hline \multicolumn{11}{|c|}{ Grouped compounds (\%) } \\
\hline \multicolumn{2}{|c|}{ Oxygenated monoterpenes } & 54.29 & 52.87 & 57.22 & 62.47 & 60.41 & 58.26 & 68.68 & 65.21 & 65.54 \\
\hline \multicolumn{2}{|c|}{ Monoterpene hydrocarbons } & 9.19 & 8.14 & 4.74 & 13.17 & 11.92 & 14.37 & 13.73 & 11.02 & 12.67 \\
\hline \multicolumn{2}{|c|}{ Oxygenated sesquiterpenes } & 10.35 & 13.64 & 13.1 & 9.36 & 9.82 & 9.59 & 7.06 & 9.35 & 8.99 \\
\hline \multicolumn{2}{|c|}{ Sesquiterpene hydrocarbons } & 19.64 & 17.99 & 15.12 & 9.93 & 8.83 & 9.37 & 6.64 & 8.43 & 6.93 \\
\hline \multicolumn{2}{|c|}{ Oxygenated diterpene } & 4.94 & 5.58 & 6.51 & 2.16 & 4.16 & 4.41 & 2.43 & 4.04 & 4.18 \\
\hline \multicolumn{2}{|c|}{ Esters } & 0.65 & 1.03 & 2.65 & 2.58 & 4.53 & 3.66 & 1.16 & 1.18 & 1.06 \\
\hline & Total & 99.06 & 99.24 & 99.35 & 99.66 & 99.67 & 99.65 & 99.7 & 99.22 & 99.37 \\
\hline
\end{tabular}

\footnotetext{
${ }^{*}$ Retention indices (RI) calculated against n-alkanes (C7-C30) on HP-Innowax column
} 
$(4.5-24.5 \%)$, 1,8-cineole $(5.5-13 \%)$, a-humulene (0$12 \%)$, a-pinene (1-6.5\%), camphene (1.5-7\%), limonene (0.5-3\%), linalool, and bornyl acetate (2.5\% maximum) have also been suggested as major $S$. officinalis compounds (ISO 9909).

The amounts of the major constituents of current findings such as $\alpha$-thujone (13-35.8\%), camphor (7$20.2 \%)$ and 1,8-cineole (6.9-14.15\%) were largely within the range of the proposed standards. Most of the compounds found in the present study have been reported in other studies on S. officinalis with different amounts (Mirjalili et al. 2006, Ben-Farhat et al. 2016, Rguez et al. 2018, Katar et al. 2019).

\section{Conclusion}

In this study, the influence of phenological cycle and diurnal variation were investigated on the content and chemical properties of VOs of S. officinalis sampled in Afyonkarahisar/Turkey. The quantity and quality of plant VOs were significantly affected by harvesting times. Based on the obtained results, the highest synthesis of VO occurred in the full flowering stage and at 8:00 p.m. The VO compositions of the plant varied widely at different growing stages and harvesting times (ontogeny and diurnal). The effects of climatic factors such as day length, insolation, temperature and also plant growth stage on these changes were evident. Knowing the agronomic and chemical properties and accurately determining the

\section{References}

1. Adams, R.P. 2007. Identification of essential oil components by gas chromatography/mass spectrometry, $4^{\text {th }}$ ed. Allured Publishing Co., Carol Stream, 804 pp.

2. Asghari, G., Gholamali, H., Mahmoudi, Z. \& Asghari M. 2014. Diurnal variation of essential of the oil components of Pycnocycla spinosa Decne. ex Boiss. Jundishapur Journal of Natural Pharmaceutical Products, 9(1): 35-38. https://doi.org/10.17795/jjnpp-12229

3. Azarnivand, H., Ghavam Arabani, M., Sefidkon, F. \& Tavili, A. 2010. The effect of ecological characteristics on quality and quantity of the essential oils of Achillea millefolium L. subsp. millefolium. Iranian Journal of Medicinal and Aromatic Plants, 25(4): 556-571.

4. Ben-Farhat, M., Jordán, M.J., Chaouch-Hamada, R., Landoulsi, A. \& Sotomayor, J.A. 2016. Phenophase effects on sage (Salvia officinalis L.) yield and composition of essential oil. Journal of Applied Research on Medicinal and Aromatic Plants, 3(3): 87-93. https://doi.org/10.1016/j.jarmap.2016.02.001

5. Ben-Taarit, M., Msaada, K., Hosni, K., Chahed, T. \& Marzouk, B. 2010. Essential oil composition of Salvia verbenaca L. growing wild in Tunisia. Journal of Food Biochemistry, 34(1): https://doi.org/10.1111/j.1745-4514.2009.00270.x

6. Bouaziz, M., Yangui, T., Saya, S. \& Dhouib, A. 2009. Disinfectant activities of essential oils from Salvia officinalis $L$ cultivated in Tunisia. Food and Chemical Toxicology, 47(11): 2755-2760. https://doi.org/10.1016/j.fct.2009.08.005 biologically active compounds of medicinal plants at different growth stages provide a clear perspective for their purposeful use including cosmetic, medicine and food industries. Extensive research is being conducted on adaptation of $S$. officinalis, including the effects of optimal planting time, density, nutrition and irrigation on the quantity and quality of the plant under the climatic conditions of Afyonkarahisar.

\section{Acknowledgement}

We would like to show our gratitude to the director, researchers and technicians of Afyonkarahisar Medicinal and Aromatic Plants Center affiliated to the General Directorate of Forestry (Turkey) for sharing their experiences with us during this study.

Ethics Committee Approval: Since it was a systematic review, its approval to the ethics committee was not required.

Author Contributions: Concept: A.S., E.S., Desing: A.S., Execution: A.S., E.S., Material Supplying: A.S., E.S., Data Acquisition/interpretatition: A.S., E.S., Writing: A.S., E.S., Critical Review: A.S.

Conflict of Interest: The authors have no conflicts of interest to declare.

Funding: The authors received no financial support for this research.

7. Bozin, B., Mimica-Dukic, N., Samojlik, I. \& Jovin, E. 2007. Antimicrobial and antioxidant properties of rosemary and sage (Rosmarinus officinalis L. and Salvia officinalis L., Lamiaceae) essential oils. Journal of Agricultural and Food Chemistry, 55(19): 7879-7885. https://doi.org/10.1021/jf0715323

8. Bradley, P.R. 2006. British herbal compendium: a handbook of scientific information on widely used plant drugs. British Herbal Medicine Association, Exeter. 409 pp.

9. European Pharmacopoeia, 2005. $5^{\text {th }}$ ed, version 5.1. EDQM, Strasbourg.

10. Grdiša, M., Jug-Dujaković, M., Lončarić, M., CarovićStanko, K., Ninčević, T., Liber, Z., Radosavljević, I. \& Šatović, Z. 2015. Dalmatian sage (Salvia officinalis L.): A review of biochemical contents, medical properties and genetic diversity. Agriculturae Conspectus Scientificus, 80(2): 69-78.

11. ISO 9909, 1997. International Organization for Standardization. Oil of Dalmatian Sage (Salvia officinalis L.), Geneva (Switzerland).

12. Katar, N., Aydin, D. \& Katar, D. 2019. Determination of the effect of different drying temperatures on the content and chemical composition of essential oil of sage (Salvia officinalis). Biological Diversity and Conservation, 12(1): 122-127. https://doi.org/10.5505/biodicon.2019.66376

13. Lakušić, B.S., Ristić, M.S., Slavkovska, V.N., Stojanović, D.L.J. \& Lakušić, D.V. 2013. Variations in essential oil yields and compositions of Salvia officinalis (Lamiaceae) 
at different developmental stages. Botanica Serbica, 37(2): 127-139.

14. Lee, Y.L. \& Ding, P. 2016. Production of essential oil in plants: Ontogeny, secretory structures and seasonal variations. Pertanika Journal of Scholarly Research Reviews, 2(1): 1-10.

15. Miguel, M.G., Guerrero, C., Rodrigues, H., Brito, J.C., Duarte, F., Venancio, F. \& Tavares, R. 2004. Main components of the essential oils from wild Portuguese Thymus mastichina (L.) L. ssp. mastichina in different developmental stages or under culture conditions. Journal of Essential Oil Research, 16(2): 111-114. https://doi.org/10.1080/10412905.2004.9698665

16. Miraj, S. \& Kiani, S. 2016. A review study of therapeutic effects of Salvia officinalis L. Der Pharmacia Lettre, 8(6): 299-303.

17. Mirjalili, M.H., Salehi, P., Sonboli, A. \& Vala, M.M. 2006. Essential oil variation of Salvia officinalis aerial parts during its phonological cycle. Chemistry of Natural Compounds, 42(1): 19-23. https://doi.org/10.1007/s10600006-0027-4

18. Nurzyńska-Wierdak, R., Bogucka-Kocka, A., Kowalski, R. \& Borowski, B. 2012. Changes in the chemical composition of the essential oil of sweet basil (Ocimum basilicum L.) depending on the plant growth stage. Chemija, 23(3): 216-222.

19. Özgüven, M., Şener, B., Orhan, I., Sekeroğlu, N., Kırpık, M. \& Kartal, M. 2008. Effects of varying nitrogen doses on yield: yield components and artemisinin content of Artemisia annua. Industrial Crops and Products, 27(1): 6064. https://doi.org/10.1016/j.indcrop.2007.07.012

20. Paulus, D., Valmorbida, R., \& E.P. Ramos, C. 2019. Productivity and chemical composition of the essential oil of Ocimum $\times$ citriodorum Vis. according to ontogenetic and diurnal variation. Journal of Applied Research on Medicinal and Aromatic Plants, 12: 59-65. https://doi.org/10.1016/j.jarmap.2018.12.004

21. Piccaglia, R., Marotti, M. \& Dellacecca, V. 1997. Effect of planting density and harvest date onyield and chemical composition of sage oil. Journal of Essential Oil Research, 9(2): 187-191. https://doi.org/10.1080/10412905.1997.9699457
22. Ramakrishna, A. \& Ravishankar, G.A. 2011. Influence of abiotic stress signals on secondary metabolites in plants. Plant Signaling \& Behavior, 6(11): 1720-1731. https://doi.org/10.4161/psb.6.11.17613

23. Ramezani, S., Rahmanian, M., Jahanbin, R., Mohajeri, F., Rezaei, M.R. \& Solaimani B. 2009. Diurnal changes in essential oil content of coriander (Coriandrum sativum L.) aerial parts from Iran. Research Journal of Biological Sciences, 4(3): 277-281.

24. Rguez, S., Msaada, K., Daami-Remadi, M., Chayeb, I., Bettaieb Rebey, I., Hammami, M., Laarif, A. \& HamrouniSellami, I. 2018. Chemical composition and biological activities of essential oils of Salvia officinalis aerial parts as affected by diurnal variations. Plant Biosystems, 153(2): 264-272. https://doi.org/10.1080/11263504.2018.1473305

25. Sedlakova, J., Kocourkova, B., Lojkova, L. \& Kuban, V. 2003. The essential oil content in caraway species (Carum carvi L.). Horticultural Science, 30(2): 73-79. https://doi.org/10.17221/3818-HORTSCI

26. Soltanbeigi, A. 2020. Qualitative variations of lavandin essential oil under various storage conditions. Journal of Essential Oil Bearing Plants, 23(6): 1237-1252. https://doi.org/10.1080/0972060X.2020.1871076

27. Soltanbeigi, A. \& Sakartepe, E. 2020. Chemical specification of Wild Salvia tomentosa Mill. collected From Inner Aegean Region of Turkey. Journal of Medicinal and Spice Plants, 24(1): 31-35.

28. Sönmez, C. \& Bayram, E. 2017. The influences of different water and nitrogen application on some yield parameters and antioxidant activity in sage (Salvia officinalis L.). Turkish Journal of Field Crops, 22(1): 96-103. https://doi.org/10.17557/tjfc.311012

29. Verma, R.S., Padalia, R.C. \& Chauhan, A. 2012. Variation in the volatile terpenoids of two industrially important basil (Ocimum basilicum L.) cultivars during plant ontogeny in two different cropping seasons from India. Journal of Agricultural and Food Chemistry, 92(3): 626-631. https://doi.org/10.1002/jsfa.4620 